\title{
FDA and EPA setbacks, fetal nicotine, ASH Thailand and UK, tennis shame, Australian documents, Corporate Activity Project, and 2100 quotes
}

Web Watch follows issues relevant to tobacco control on the world wide web. The emphasis is on new sites or new features appearing on the web including relevant URLs and short descriptions of the material. A web site is available featuring the URL links referenced in this column as well as those referenced in past columns; the URL for that site is: <http://www. gate.net/ jcannon/webwatch/>.

\section{FDA ruling overturned}

After failing to assert its authority over tobacco products since 1914, the Food and Drug Administration (FDA) in the United States published a final rule on 28 August 1996 entitled "Regulations restricting the sale and distribution of cigarettes and smokeless tobacco to protect children and adolescents". That final rule is available at

<http://www.fda.gov/opacom/campaigns/tobacco/ frule. html>.

On 25 April 1997 Federal Judge William Osteen, a former tobacco lobbyist, upheld the FDA initiative in part, writing that "Tobacco products fit within the Food and Drug and Cosmetic Act's definition of 'drug' and 'device'." Although blocking plans to initiate restrictions on tobacco advertising and promotional activities, Judge Osteen let stand the FDA's crackdown on tobacco sales to minors that required stores to demand identity cards with photographs from people in their 20 s and imposed government regulation of cigarette sales from vending machines. That decision is available at

<http://www.tobacco.neu.edu/FDA/osteen.htm>.

On 14 August 1998 a three-judge panel of the fourth Circuit Court of Appeals voted two to one to reverse Judge Osteen's ruling imposing the FDA crackdown on tobacco sales to minors by denying the FDA authority to regulate tobacco products as drug-delivery devices. The appellate court ruled that such regulation was left up to Congress. The appellate court decision is available at

<http://www.law.emory.edu/4circuit/aug98/ 971604.p.html>.

On the same day that the court issued its decision, President Bill Clinton announced that the solicitor general had "authorized the filing of a petition in the Court of Appeals for the Fourth Circuit seeking rehearing en banc of the three-judge panel's decision regarding FDA regulation of tobacco products". If granted, the rehearing will be conducted before the full court of appeals instead of a three-judge panel. Regardless of the outcome of the petition, the matter seems destined to be heard by the Supreme Court.

Now comes Graham Kelder of the Tobacco Control Resource Center of Northeastern Uni- versity Law School in Boston, Massachusetts. In an article entitled "Reversal of fortune", Graham has provided a comprehensive analysis of the legal issues associated with the appellate court decision. Quoting extensively from Judge Kenneth K Hall's lone dissenting opinion, Graham's article is available at

<http://www.tobacco.neu.edu/FDA/

FDAdecicionarticle. $h$ tm $>$.

\section{Osteen vacates EPA finding}

Hailed as the new hero of the tobacco industry, Judge William Osteen issued a ruling on 19 July 1998 that the United States Environmental Protection Agency (EPA) wrongly declared secondhand tobacco smoke a dangerous carcinogen in a landmark 1993 report. In his ruling, the tobacco-lobbyist-turned-federal-judge wrote, "The court vacates Chapters 1-6 of and the Appendices to EPA's Respiratory Health Effects of Passive Smoking: Lung Cancer and other Disorders". The complete text of Judge Osteen's ruling is available at

$<$ http://www.tobacco.org/Documents/

980717osteen.html>.

Noting that the ruling was based on procedural issues-not scientific findingsEPA administrator Carol $M$ Browner has promised an appeal.

Again comes Graham Kelder of the Tobacco Control Resource Center with another comprehensive analysis of the legal issues surrounding Judge Osteen's ruling. Entitled "MISTAKEN RULING, UNMISTAKABLE FACTS: how Judge Osteen got it wrong when he vacated the EPA's finding that secondhand smoke is a known carcinogen and why his ruling may not matter", Graham's analysis is available at <http://www.tobacco.neu.edu/Extra/hotdocs/ OsteenArticle.htm>.

\section{Fetal nicotine-cigarette babies}

"Massive numbers" of fetal deaths, crib (cot) deaths, and severe neurological problems are the burden "cigarette babies" must carry for maternal smoking. Yet these numbers do not take into account the enormous increase in correspondence to

jcannon@gate.net 


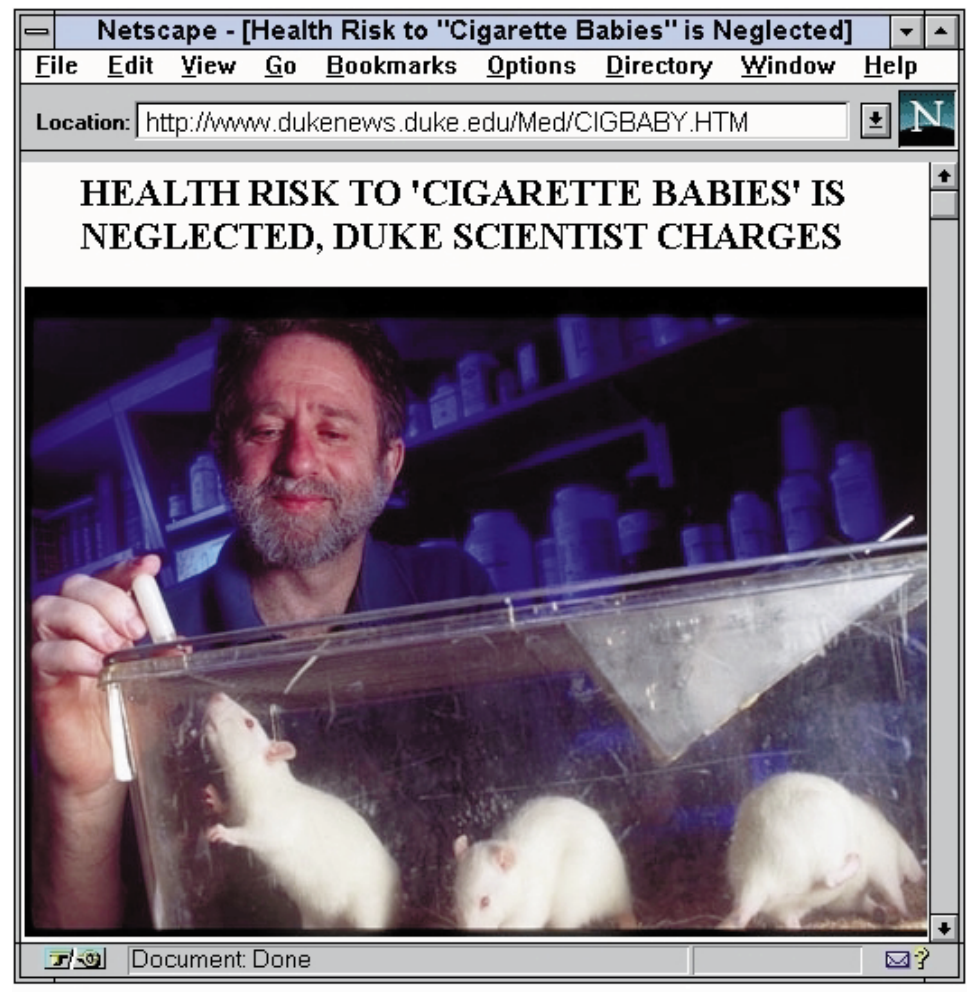

Figure 1 Professor Theodore Slotkin of the Duke University Medical Center in North Carolina (United States) compares the fetal effects of nicotine and cocaine exposure.

learning disabilities, attention deficit hyperactivity disorder, and other behavioural problems also known to result from maternal smoking.

These are the conclusions of Professor Theodore A Slotkin, Department of Pharmacology and Cancer Biology, Duke University Medical Center in Durham, North Carolina, United States (figure 1).

Noting that illicit drugs account for only a handful of deaths annually, alcohol 50 000, and tobacco 400 000, Professor Slotkin cites a survey of medical pharmacology texts showing that more than $80 \%$ of the pages devoted to substance abuse concerned illicit drugs, just over $10 \%$ were about alcohol, and less than $5 \%$ concerned tobacco.

"Widespread, chronic ingestion of nicotine by one-fourth of all pregnant women probably produces far more damage than the more limited and episodic use of cocaine", Professor Slotkin concludes. "Although scientists and the public continue to pay far more attention to fetal cocaine effects than to those of nicotine or tobacco use, a change of focus to concentrate on tobacco could have a disproportionately larger impact on human health."

Professor Slotkin bases his conclusions on a thorough review of research findings. Those findings have been detailed in a paper entitled "Fetal nicotine or cocaine exposure: which one is worse?" His paper has been published in the June 1998 issue of the fournal of Pharmacology and Experimental Therapeutics. It is also available at

$<$ http://www.dukenews.duke.edu/nicotine/ slotkin.htm>.
The press release is available at $<$ http://www.dukenews.duke.edu/Med/ CIGBABY.HTM>

Action on Smoking and Health-Thailand $<h t t p: / / w w w . a s h . o r . t h />$

Formed in 1986 through the efforts of 12 health organisations in Thailand, the Action on Smoking and Health Foundation of Thailand is a non-government organisation (figure 2). Under the name Thai AntiSmoking Campaign Project (TASCP), the organisation was the first to deal exclusively with tobacco control. In 1997 TASCP changed its name to Action on Smoking and Health (ASH) and became a foundation in its own right.

The Thai Action on Smoking and Health Foundation (ASH) runs the following projects targeting different segments of the community.

- A clearinghouse for tobacco information to house the many journals, newsletters, books and general information on tobacco which it and other health organisations have collected over the years

- Training for health workers and teachers in promoting non-smoking values

- A quitline telephone counselling service for smokers, operating through the support of the Telephone Authority of Thailand

- The Smokebuster Caravan-a mobile education unit fitted with displays and information about smoking

- Care for Kids - a programme that targets children aged 3-12 years old, tries to educate them about the dangers of smoking, and builds up positive images of non-smoking

- Smoke-free Schools 2000-a holistic programme that targets teenagers in and out of school for the promotion of a positive non-smoking image

- The Thai Women Don't Smoke programme - a project to foster the traditional non-smoking values of Thai women

- Smokefree Areas - a programme to raise public awareness of indoor air pollution caused by cigarette smoking, particularly in the workplace, restaurants, and temples

- The Tobacco Control Policy Research Network (TCPRN) - a programme that encourages tobacco control research to strengthen tobacco control policy and promote health.

\section{Action on Smoking and Health-United}

\section{Kingdom}

<http://www.ash.org.uk/>

Tobacco Explained-the truth about the tobacco industry in its own words-is an outstanding analysis of many of the industry documents and statements.

Thousands of internal tobacco industry documents released through litigation and whistleblowers reveal the most astonishing systematic corporate deceit of all time. ASH-UK has undertaken a survey of these internal tobacco industry documents and extracted 1200 relevant and revealing quotes, 


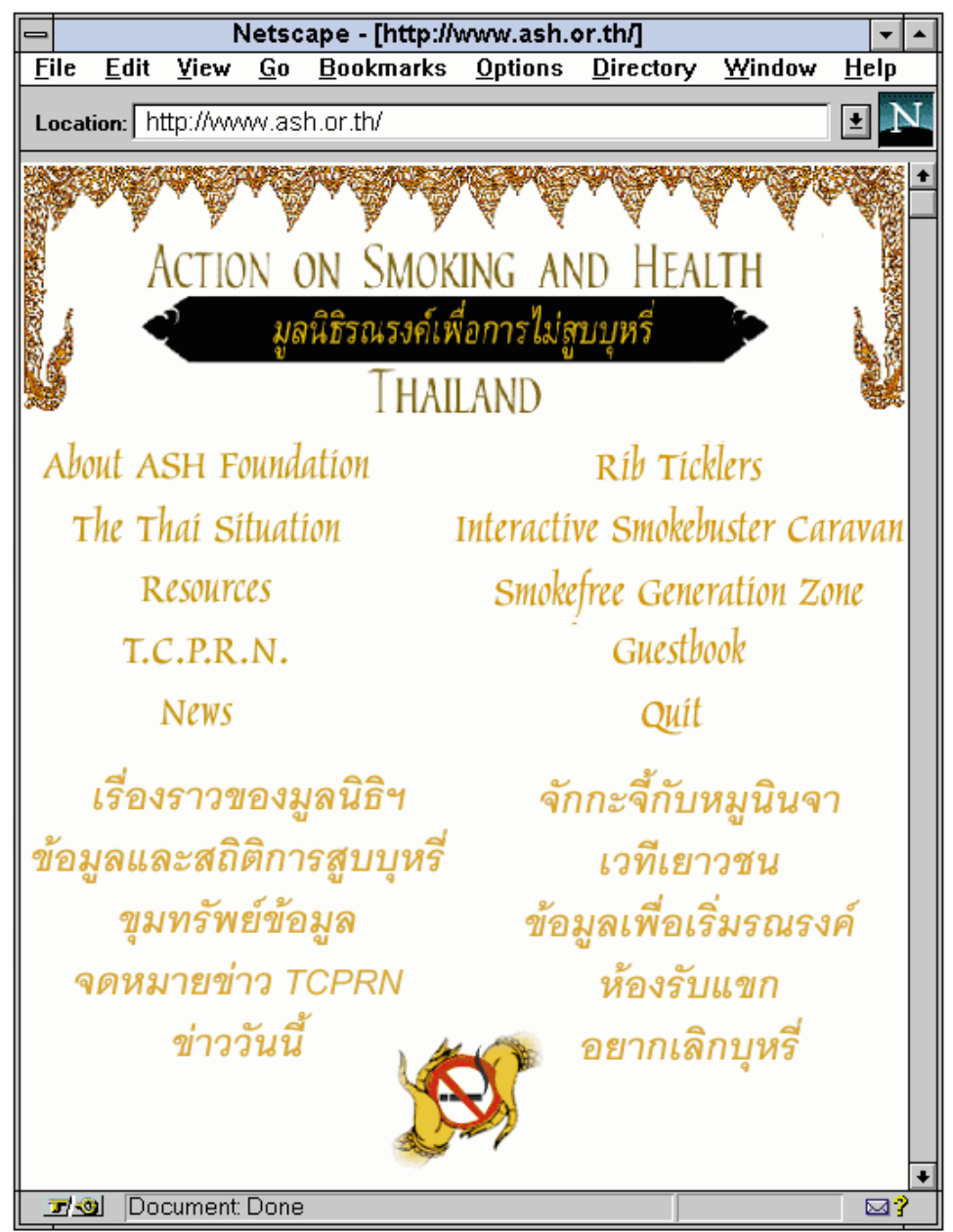

Figure 2 Web site for Action on Smoking and Health-Thailand.

then grouped these together under common themes. Those themes are: smoking and health, nicotine and addiction, marketing to children, advertising, cigarette design, passive smoking, and emerging markets.

\section{Canadian Open Tennis Hall of Shame}

$<h t t p: / / s e e r c o m . c o m / a i r s p a c e / t e n n i s \_s h a m e . h t m l>$ Bob Broughton has added the "Canadian Open Tennis Hall of Shame" to his AIRSPACE web page. The Hall of Shame documents shady financial dealings on the part of Tennis Canada, and how faithfully executives of Tennis Canada respond to requests from Imperial Tobacco.
Industry documents pertinent to Australia <http://www.health.usyd.edu.au/tobacco/

Ozdocs.htm>

Need to browse a library of tobacco industry documents with specific relevance to Australia? Tobacco Control deputy editor Simon Chapman has updated his Tobacco Control Supersite to include links to dozens of such links. Check it out.

\section{Corporate Activity Project}

<http://www.tobacco.org/Documents/ jonesday1.html>

Once again Gene Borio has provided us with yet another fascinating document. This massive document (449 pages) offers a unique insight to the history of tobacco industry wrongdoings. Drafted by the tobacco industry law firm of Jones, Day, Reavis \& Pogue, the Corporate Activity Project details a history over four decades of the industry's corporate misconduct pertaining to the issues and the evidence that plaintiffs' counsel can be expected to present in legal proceedings. The subject matter ranges from "Safe cigarettes" and "Smoking beagles" to "Addiction vs habituation".

The document (Bates No 681879254), which is in TIFF format, is 27 megabytes. However, Gene has converted it to text with a high degree of accuracy. This text version is a much more reasonable size, is searchable, and can be accessed in real time.

\section{Gene Borio's notable and quotable} <http://www.smokescreen.org/>

Gene Borio's collection of more than 2100 quotes about tobacco and the tobacco industry is now available online in a fast, searchable format. More than 100 relate to the "settlement"- the 20 June 1998 agreement (now abandoned) between tobacco manufacturers and the several state attorneys general who had sued them.

Once logged into Michael Tacelosky's Smokescreen website, just click on "Quotes" under the "Resources" database menu.

See "Play It Again" on pages 301-309 of this issue for a sampling of these quotes. 